\title{
Chylothorax Due to Weight Lifting: A Rare Etiology
}

\author{
( Illker Kolbaş, ${ }^{1}$ (1) Yelda Tezel, ${ }^{2}$ (1) Tuğba Coşgun, ${ }^{3}$ \\ (1) Volkan Baysungur, ${ }^{4}$ (1) Çağatay Tezel ${ }^{4}$
}

\author{
'Department of Thoracic Surgery, \\ İstanbul Sultan Abdulhamid Han \\ Training and Research Hospital, \\ Istanbul, Turkey \\ ${ }^{2}$ Department of Pulmonology, \\ Haydarpaşa Numune Training and \\ Research Hospital, İstanbul, Turkey \\ ${ }^{3}$ Department of Thoracic Surgery, \\ İstanbul Bilim University Faculty of \\ Medicine, İstanbul, Turkey \\ ${ }^{4}$ Department of Thoracic Surgery, \\ Süreyyapaşa Chest Disease and \\ Thoracic Surgery Training and \\ Research Hospital, İstanbul, Turkey \\ Submitted: 21.11.2018 \\ Accepted: 20.08.2019 \\ Correspondence: İlker Kolbaș \\ İstanbul Sultan Abdulhamid Han \\ Eğitim ve Araştırma Hastanesi, \\ Göğüs Cerrahisi Kliniği, \\ İstanbul, Turkey \\ E-mail:dr_ilkerkolbas@hotmail.com

E-mail:dr_ilkerkolbas@hotmail.com
Keywords: Pleural effusion;
scalene muscle; traumatic
chylothorax.
This work is licensed under a creative Commons \\ This work is licensed under a Creative Commons
Attribution-NonCommercial 40 International License.
}

\begin{abstract}
Chylothorax cases are associated with several etiologies. Non-Hodgkin lymphoma and intrathoracic surgical trauma are the most frequent reasons, but approximately $15 \%$ of the cases are idiopathic. Idiopathic chylothorax is thought to be related to minor trauma, and damage above the fifth thoracic vertebra is known to lead to left-sided effusion. In this report, we describe a left-sided chylothorax with an etiology that was finally identified by an in-depth interrogation of the patient's past medical history. Several days previously, while he was weight training with his left arm, he experienced serious pain in his scalenus anterior muscle area. We thought that overstretching of the subclavious and anterior scalenus muscle might have led to the rupture of the left lymphatic duct. Traumatic chylothorax after weight lifting is a rare entity. Awareness and a high degree of suspicion are important in cases of unusual pleural effusion.
\end{abstract}

\section{INTRODUCTION}

Chylothorax is the collection of chyle in the pleural space due to traumatic and/or medical reasons. Chylothorax causes several detrimental symptoms, especially dyspnea. Postoperative iatrogenic chylothorax is the most common cause. ${ }^{[l]}$ Here, we present a case of chylothorax caused by weight lifting.

\section{CASE REPORT}

A thirty-four-year-old non-smoker man who had no history of any previous health problems was admitted with ongoing dyspnea for almost 2 weeks. His height was 180 $\mathrm{cm}$, and his weight was 90 kilograms. The patient signified in his detailed medical history that he had felt chest pain and dyspnea after weight lifting forty kilograms at a fitness center two weeks ago.

His chest roentgenogram revealed a left pleural effusion. Thorax computed tomography confirmed a large pleural effusion in the left hemithorax, with no mediastinal lymph node or mass. The milky fluid was obtained by thoracentesis and a tube thoracostomy was performed. A total of $3500 \mathrm{cc}$ of milky fluid was drained from the chest tube. His symptoms decreased rapidly.

At the same time, samples from pleural fluid were sent to the laboratory for biochemistry and cytology tests. Analysis of the fluid showed a triglyceride level of $2174 \mathrm{mg} /$ $\mathrm{dL}$, the cholesterol level of $89 \mathrm{mg} / \mathrm{dL}$, and a total protein 
level of $4.19 \mathrm{mg} / \mathrm{dL}$. Direct mycological examination and cultures were negative. Fluid cytology showed mesothelial cells, lymphocytes, and histiocytes.

As a conservative approach, oral intake was stopped, and total parenteral nutrition was started. By this time, his drainage was recorded daily. By the $10^{\text {th }}$ day, the patient had no further drainage from the chest tube and an oral intake was restarted. We terminated the chest tube and discharged the patient on the $12^{\text {th }}$ day. There were no problems on his follow-up physical examinations and $x$ rays. Patient's consent was obtained for this study.

\section{DISCUSSION}

Chylothorax is the collection of chyle in the pleural space. Chyle fluid passes from the cisterna chyli through the thoracic duct into the venous system. Chylothorax is associated with multiple etiologies, including traumatic and non-traumatic reasons. Non-Hodgkin lymphoma is the most frequent non-traumatic cause, whereas no reason can be found for the chylous pleural effusion in approximately $15 \%$ of the cases. These idiopathic chylothoraces are mostly considered to be related to minor trauma. ${ }^{[2]}$

The thoracic duct emerges when cisterna chyle ascends through the aortic hiatus of the diaphragm between the aorta and the azygos vein into the posterior mediastinum. The thoracic duct crosses the left side at the level of the fifth thoracic vertebra and ascends behind the aortic arch; it then turns laterally and anteriorly at the seventh cervical vertebra. It terminates near the junction of the internal jugular and subclavian veins. ${ }^{[1]}$ The musculus subclavius and musculus scalenus anterior are located in this area and function in the upper limb movement (Fig. I).

The musculus scalenus anterior has a function in inspiration, as well as constituting superficial neck flexors with the musculus sternocleidomastoid. ${ }^{[3]}$ Although not used directly during weight lifting exercises, the anterior scalene muscle and subclavian muscles have functions during deep inspiration. If neck flexion is performed at the same time as inspiration during weight lifting exercises in a supine position, the anterior scalene triangle, in particular, becomes smaller. Subclavian vein obstruction may occur with subclavius and anterior scalene muscle compression. ${ }^{[4]}$ The

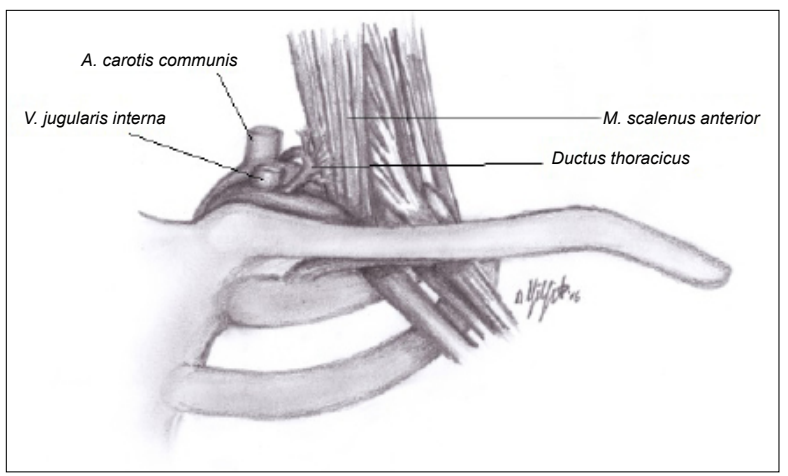

Figure 1. Anatomical image of ductus thoracicus and anterior scalene muscle. ductus thoracicus frequently empties into the junction of the jugular and subclavian veins, so that we hypothesize that overextension or injury of the ductus may lead to chylothorax. Although not reported previously, our opinion is that overstretching of the subclavius and anterior scalenus muscle injured the ductus thoracicus in our case.

The majority of ingested fats are taken into the systemic circulation using the ductus thoracicus. Approximate 2500 milliliters of chyle is introduced daily into the systemic circulation. $^{[5]}$ Depending on the chylous losses, chylothorax may cause dehydration, hypoproteinemia, fat-soluble vitamin loss, and immunologic impairment. ${ }^{[5]}$

Generally, the symptoms of chylothorax are nonspecific and relate to the rate of accumulation of chyle. The most common symptom is dyspnea due to the collection of pleural fluid. Chest pain and fever are rare because chyle is not irritating to the pleural surface. ${ }^{[6]}$ The symptoms in our case were the common ones of chest pain and dyspnea.

The diagnosis of chylothorax is made by the analysis of the pleural fluid. The chylous fluid is a opaque white liquid with mild odor. ${ }^{[7]}$ The liquid profiles of the blood and pleural fluid led to the diagnosis of chylothorax in our case.

Treatment of chylothorax, especially in patients with underlying malign diseases, includes the conservative approach, surgery, chemotherapy, and radiotherapy. ${ }^{[8]}$ The first treatment should be a conservative approach, as there is no necessity for an emergency operation. Conservative approach steps include placing a chest tube, stopping oral intake, and starting total parenteral nutrition. This treatment must continue for 10-14 days. Between 20 and $80 \%$ of the lacerations of the thoracic duct can resolve with conservative treatment. ${ }^{[8]}$ When conservative treatment fails, surgical treatment should be considered cautiously because of high mortality. Alternatively, talc pleurodesis, intrapleural tetracycline infusion, intrapleural bleomycin, and fibrin glue can be used in the treatment of chylothorax. ${ }^{[8]}$ If chylous effusion continues, surgical ligation becomes an option. Although surgical treatment is successful in about $90 \%$ of the cases, it has relatively high mortality and morbidity rates due to this, patients are severely ill. ${ }^{[8]}$ Radiotherapy has also seen increasing use in chylothorax treatment in recent years. ${ }^{[9]}$ In our case, we treated our patient with a conservative approach.

Several different and rare diseases have been reported in association with weight liftings, such as pneumothorax, pneumomediastinum, or dissection of the coronary artery. [10-12] Therefore, athletes and physicians must remain aware of these issues and the extraordinary symptoms that may occur during and after this kind of exercise.

\section{CONCLUSION}

In conclusion, chylothorax may occur following the extreme movements of the left upper limb. In our case, we demonstrated that a minor trauma occurring during a weight lifting exercise could lead to chylothorax. There- 
fore, in patients with idiopathic chylothorax, trauma should be kept in mind, and a detailed history of the patient should be taken.

\section{Acknowledgement}

We thank Nurettin Yigit for drawing of the figure in this study.

\section{Informed Consent}

Written informed consent was obtained from of the patient for the publication of the case report and the accompanying images.

Peer-review

Internally peer-reviewed.

Authorship Contributions

Concept: I.K., Y.T.; Design: T.C., Ç.T.; Supervision: Y.T., V.B.; Materials: Ç.T., Y.T.; Data: I.K., T.C.; Analysis: Ç.T., V.B.; Literature search: Y.T., I.K.; Writing: I.K., T.C.; Critical revision: Y.T., V.B., I..K.

\section{Conflict of Interest}

None declared.

\section{REFERENCES}

1. Talwar A, Lee HJ. A contemporary review of chylothorax. Indian J Chest Dis Allied Sci 2008;50:343-51.
2. García-Aparicio J, Herrero-Herrero JI, Corral-Gudino L, JorgeSánchez RJ. Bilateral idiopathic chylothorax associated with light physical exercise. Respiratory Medicine CME 2009;2:68-9. [CrossRef]

3. Jull G, Falla D. Does increased superficial neck flexor activity in the craniocervical flexion test reflect reduced deep flexor activity in people with neck pain? Man Ther 2016;25:43-7. [CrossRef]

4. McCleery RS, Kesterson JE, Kirtley JA, Love RB. Subclavius and anterior scalene muscle compression as a cause of intermittent obstruction of the subclavian vein. Ann Surg 1951;133:588-602. [CrossRef]

5. Platis IE, Nwogu CE. Chylothorax. Thorac Surg Clin 2006;16:20914. [CrossRef]

6. Romero S. Nontraumatic chylothorax. Curr Opin Pulm Med 2000;6:287-91. [CrossRef]

7. Staats BA, Ellefson RD, Budahn LL, Dines DE, Prakash UB, Offord $\mathrm{K}$. The lipoprotein profile of chylous and nonchylous pleural effusions. Mayo Clin Proc 1980;55:700-4.

8. Schild HH, Strassburg CP, Welz A, Kalff J. Treatment options in patients with chylothorax. Dtsch Arztebl Int 2013;110:819-26. [CrossRef]

9. Sziklavari Z, Allgäuer M, Hübner G, Neu R, Ried M, Grosser C, et al. Radiotherapy in the treatment of postoperative chylothorax. J Cardiothorac Surg 2013;8:72. [CrossRef]

10. Ciocca M Jr. Pneumothorax in a weight lifter: the importance of vigilance. Phys Sportsmed 2000;28:97-103. [CrossRef]

11. Sadarangani S, Patel DR, Pejka S. Spotaneous pneumomediastinum and epidural pneumatosis in an adolescent precipitated by weight lifting: a case report and review. Phys Sportsmed 2009;37:147-53.

12. Yiangou K, Papadopoulos K, Azina C. Heavy Lifting Causing Spontaneous Coronary Artery Dissection with Anterior Myocardial Infarction in a 54-Year-Old Woman. Tex Heart Inst J 2016;43:189-91.

\section{Ağırlık Kaldırma Sonrası Şilotoraks: Nadir Bir Etiyoloji}

Şilotoraks çeşitli nedenlerle oluşabilir. Non-Hodgkin lenfoma ve intratorasik cerrahi travma en sık nedenlerdir, olguların yaklaşık \% I5'i idiyopatiktir. İdiyopatik şilotoraksın minimal travma ile ilişkili olduğu düşünülmektedir ve beşinci torasik vertebra seviyesinin üstündeki hasarlarda sol hemitoraksta efüzyona yol açtığı bilinmektedir. Olgumuzda, hastanın geçmiş tıbbi öyküsünün derinlemesine sorgulanmasıyla tanımlanan bir etiyolojiye sahip bir sol tarafta şilotoraks tespit ettik. Hastanın öyküsünde; birkaç gün önce, sol koluyla ağırlık çalışırken, anteriyor skalen kas bölgesinde ciddi bir ağrı yaşadığını ögrendik. Subklavius ve anteriyor skalen kasının aşırı gerilmesinin sol lenfatik kanalın rüptürüne yol açabileceğini düşündük. Ağırlık kaldırma sonrası travmatik şilotoraks nadir görülen bir durumdur. Sıradışı plevral efüzyon olgularında tanı için farkındalık ve şüphe önemlidir.

Anahtar Sözcükler: Plevral efüzyon; skalen kas; travmatik şilotoraks. 